\title{
Clinical factors impacting quality of life and outcomes through the transition from pre-dialysis chronic kidney disease to early dialysis treatment
}

Citation for published version (APA):

Maddux, D. W. (2018). Clinical factors impacting quality of life and outcomes through the transition from pre-dialysis chronic kidney disease to early dialysis treatment. [Doctoral Thesis, Maastricht University]. Datawyse / Universitaire Pers Maastricht. https://doi.org/10.26481/dis.20181218dm

Document status and date:

Published: 01/01/2018

DOI:

10.26481/dis.20181218dm

Document Version:

Publisher's PDF, also known as Version of record

Please check the document version of this publication:

- A submitted manuscript is the version of the article upon submission and before peer-review. There can be important differences between the submitted version and the official published version of record.

People interested in the research are advised to contact the author for the final version of the publication, or visit the DOI to the publisher's website.

- The final author version and the galley proof are versions of the publication after peer review.

- The final published version features the final layout of the paper including the volume, issue and page numbers.

Link to publication

\footnotetext{
General rights rights.

- You may freely distribute the URL identifying the publication in the public portal. please follow below link for the End User Agreement:

www.umlib.nl/taverne-license

Take down policy

If you believe that this document breaches copyright please contact us at:

repository@maastrichtuniversity.nl

providing details and we will investigate your claim.
}

Copyright and moral rights for the publications made accessible in the public portal are retained by the authors and/or other copyright owners and it is a condition of accessing publications that users recognise and abide by the legal requirements associated with these

- Users may download and print one copy of any publication from the public portal for the purpose of private study or research.

- You may not further distribute the material or use it for any profit-making activity or commercial gain

If the publication is distributed under the terms of Article 25fa of the Dutch Copyright Act, indicated by the "Taverne" license above, 


\section{Summary}

This thesis examines clinical and laboratory parameters and clinical interventions through late stage chronic kidney disease (CKD) and the transition to dialysis start that impact outcomes in the early dialysis period. This research utilizes a unique CKD dataset that includes continuous pre- and post-dialysis start data. In this research key parameters and interventions known to be associated with patient outcomes including cardiovascular, nutritional, mineral metabolism, and inflammatory parameters as well as quality of life (QOL), educational, and case management measures and interventions were explored.

In Chapter 2 the examination of presystolic blood pressure (preSBP) and ultra-shortterm mortality yielded insights into the increased risk of short-term mortality for low preSBP from the first day of dialysis and throughout the first dialysis year. This data highlights the need for dialysis clinicians to consider timely additional assessments for dialysis patients with low and low-normal preSBP especially in the early dialysis period.

In Chapter 3 key clinical parameters including BP, albumin, and white blood cell (WBC) count as indicators of cardiovascular, nutrition, and inflammation were assessed in late stage CKD through the transition to dialysis start. These clinical parameters were shown to diverge before dialysis start for patients who survive versus do not survive the early months of dialysis. Such findings suggest that it may be possible to identify patients at risk for poor early dialysis outcomes and provide additional care, support, or interventions in the months before dialysis start.

Chapter 4 reports an improved dialysis start for patients who receive specific interventions delivered in a case-management CKD program. This improved, optimal dialysis start including use of a home therapy and a permanent access is associated with better dialysis outcomes demonstrating the impact of late stage CKD care in early dialysis outcomes.

Chapter 5 compares late stage CKD clinical parameters throughout the time of transition to dialysis start for peritoneal dialysis (PD) versus hemodialysis (HD) starters. Some previous research suggests that PD starters have better early dialysis outcomes compared to HD starters, but PD versus HD case mix comparison traditionally only includes data from the early dialysis period. Our data suggest that key parameters associated with the rate of CKD progression, nutrition, inflammation, and cardiovascular stability differ in the months prior to dialysis start for PD versus HD starters. Future research in early dialysis outcomes for PD versus HD starters may need to account for pre-dialysis start variability. 
Chapter 6 highlights the impact on QOL of switching from HD to PD or vice versa during the first year of dialysis. QOL as measured by the Kidney Disease Quality of Life (KDQOL) instrument is known to be associated with clinical outcomes, yet no recommendation currently exists for QOL assessment or interventions to improve QOL at the time of switching from PD to HD or vice versa which may be of particular importance during the early dialysis period. 